Volume 54

Issue 2 Volume 54, Issue 2 (Winter 2017)

Special Issue: Introduction to the Law and

Markets: Regulating Controversial Exchange

Article 7

Guest Editors: Kimberly Krawiec, Poonam Puri

and Mitu Gulati

6-1-2017

\title{
A Market for Sovereignty? The Roles of Other States in Self- Determination
}

Karen Knop

University of Toronto

Follow this and additional works at: https://digitalcommons.osgoode.yorku.ca/ohlj

Part of the International Law Commons

Special Issue Commentary

\section{(i) $\Theta($}

This work is licensed under a Creative Commons Attribution-Noncommercial-No Derivative Works 4.0 License.

\section{Citation Information}

Knop, Karen. "A Market for Sovereignty? The Roles of Other States in Self-Determination." Osgoode Hall Law Journal 54.2 (2017) : 491-510.

https://digitalcommons.osgoode.yorku.ca/ohlj/vol54/iss2/7

This Special Issue Commentary is brought to you for free and open access by the Journals at Osgoode Digital Commons. It has been accepted for inclusion in Osgoode Hall Law Journal by an authorized editor of Osgoode Digital Commons. 


\title{
A Market for Sovereignty? The Roles of Other States in Self-Determination
}

\begin{abstract}
How can the popular sovereignty associated with international law's regulation of self-determination (secession) be reconciled with the state's traditional property-like prerogative to transfer (cede) territory regardless of the inhabitants' wishes? Joseph Blocher and Mitu Gulati innovatively propose a "market" for sovereignty that would treat secession more like a sale of property, and cession, less.

Existing international law does not conceive of states as potential bidders, buyers, backers, underwriters or investors in a people's exercise of self-determination. However, international lawyers should not overestimate the differences with Blocher and Gulati's unconventional proposal. Compared to their idea of market-generated options for sovereignty, the generation of options pursuant to a right of selfdetermination appears murky in international law. Questions about the rights and duties of other states and the limits on outside investment in a people's independence were legally salient in colonial selfdetermination-a doctrinal category of self-determination that Blocher and Gulati neglect. These questions deserve renewed attention in any analytical and critical stock-taking of self-determination in international law.
\end{abstract}

\section{Keywords}

Self-determination, National

\section{Creative Commons License} c) (ㅇ) $\ominus$

This work is licensed under a Creative Commons Attribution-Noncommercial-No Derivative Works 4.0 License.

\section{Cover Page Footnote}

I thank Patrick Macklem and participants in the Law for Sustainable Socio-Economic Development Conference, Centre for International Governance Innovation, Waterloo for helpful questions and comments. 


\title{
Special Issue Commentary
}

\section{A Market for Sovereignty? The Roles of Other States in Self-Determination*}

\author{
KAREN KNOP ${ }^{\dagger}$
}

How can the popular sovereignty associated with international law's regulation of self-determination (secession) be reconciled with the state's traditional property-like prerogative to transfer (cede) territory regardless of the inhabitants' wishes? Joseph Blocher and Mitu Gulati innovatively propose a "market" for sovereignty that would treat secession more like a sale of property, and cession, less.

Existing international law does not conceive of states as potential bidders, buyers, backers, underwriters or investors in a people's exercise of self-determination. However, international lawyers should not overestimate the differences with Blocher and Gulati's unconventional proposal. Compared to their idea of market-generated options for sovereignty, the generation of options pursuant to a right of self-determination appears murky in international law. Questions about the rights and duties of other states and the limits on outside investment in a people's independence were legally salient in colonial self-determination-a doctrinal category of self-determination that Blocher and Gulati neglect. These questions deserve renewed attention in any analytical and critical stock-taking of self-determination in international law.

Comment concilier, d'une part, la souveraineté populaire associée aux règles du droit international en matière d'autodétermination (sécession) et, d'autre part, la prérogative traditionnelle de l'État de transférer (céder) son territoire indépendamment de la volonté de ses habitants? Joseph Blocher et Mitu Gulati postulent de manière innovante l'existence d'un « marché » de la souveraineté au sein duquel la sécession se rapproche davantage de la vente de biens que la cession.

* An earlier version of this article was presented at the Law \& Markets: Regulating

Controversial Exchange Symposium on 15 September 2015 at Osgoode Hall Law School, Toronto.

$+\quad$ Faculty of Law, University of Toronto. I thank Patrick Macklem and participants in the Law for Sustainable Socio-Economic Development Conference, Centre for International Governance Innovation, Waterloo for helpful questions and comments. 
Le droit international en vigueur ne conçoit pas les États comme des soumissionnaires, des acheteurs, des bailleurs de fonds, des preneurs fermes ou des investisseurs potentiels dans l'exercice du droit d'un peuple à disposer de lui-même. Toutefois, les spécialistes du droit international ne devraient pas surestimer les différences existant avec la vision non conventionnelle de Blocher et Gulati. Comparativement à leur théorie selon laquelle les forces du marché génèrent des options de souveraineté, l'identification des options visant le droit à l'autodétermination ne coule pas de source en droit international. Les questions afférentes aux droits et devoirs des autres États et aux limites des investissements externes en faveur de l'indépendance d'un peuple revêtaient une importance juridique cruciale dans le contexte de l'autodétermination coloniale, une catégorie doctrinale de l'autodétermination négligée par Blocher et Gulati. Ces questions méritent un regain d'attention dans le cadre de toute discussion analytique et critique du concept d'autodétermination en droit international.

I. PICTURING SELF-DETERMINATION...

II. UNDERMINING SELF-DETERMINATION?.

III. REVISITING THE ROLES OF OTHER STATES IN SELF-DETERMINATION ................................ 502

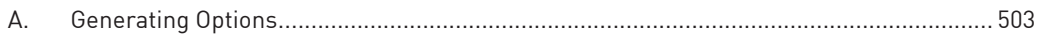

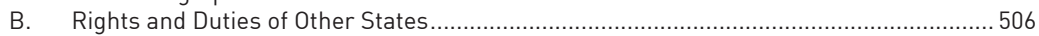

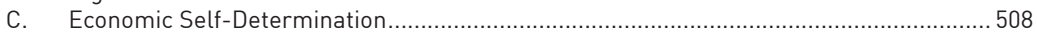

\section{PICTURING SELF-DETERMINATION ${ }^{1}$}

\section{“THE DEFINING ISSUE IN INTERNATIONAL LAW FOR THE 21ST CENTURY,”} Joseph Blocher and Mitu Gulati quote, "is finding compromises between the principles of self-determination and the sanctity of borders." ${ }^{2}$ When does self-determination give a people the right to choose the sovereign borders

1. This article responds to two related articles by Joseph Blocher \& Mitu Gulati: Part I of "Markets and Sovereignty" (2016) 54 Osgoode Hall LJ 463 ["Markets and Sovereignty"] and "A Market for Sovereign Control" (2017) 66 Duke LJ 797 ["A Market"].

2. "Markets and Sovereignty", supra note 1 at 472, n 31; 476-77; "A Market", supra note 1 at 813 (quoting Michael P Scharf, "Earned Sovereignty: Juridical Underpinnings" (2003) 31 Denv J Intl L \& Pol'y 373 at 373, quoting Lorie M Graham, "Self-Determination for Indigenous Peoples After Kosovo: Translating Self-Determination 'Into Practice' and 'Into Peace'” (2000) 6 ILSA J Intl \& Comp L 455 at 465). Compare Scharf, writing in 2003, with Zoran Oklopcic, "The Anxieties of Consent: Theorizing Secession between Constitutionalism and Self-Determination” (2015) 22 Int'l J on Minority \& Group Rights 259 ("while the post-communist secessionist tsunami of the early 1990s has long abated, the question of secession continues to irritate our preconceptions of what, if anything, should constitutional and international law 'do' when confronted with demands for independent statehood" at 261). 
within which they live, and when does the countervailing principle of territorial integrity (the sanctity of borders) give their state the authority to resist such desire to leave? As a principle, self-determination has informed a range of legal questions, settlements and institutional arrangements across a range of historical periods and geographic regions dating from at least the First World War. In the 1960s, for instance, it yielded a right of decolonization, while the principle of territorial integrity confined that right to overseas colonies. ${ }^{3}$ The current question is typically whether, and if so when, a group within the territory of a state is entitled to independence. ${ }^{4}$

In "Markets and Sovereignty" and a longer article on optimizing international borders, ${ }^{5}$ Blocher and Gulati reframe the challenge. They place the usual scenario, in which a region seeks to separate and the state wants the status quo, side by side with its opposite: the state seeks to dispose of the region, and the region's population may wish to remain. Thus the authors contrast a group's desire to break away (secede) against the state's wishes, with the state's traditional sovereign prerogative to transfer (cede) territory to another state regardless of its inhabitants' wishes. How can the popular sovereignty associated with international law's regulation of self-determination be reconciled with international law's model of the state as a property owner when it comes to ceding territory?6 Blocher and Gulati innovatively propose a "market" for sovereignty that would re-align the existing commodification of sovereignty such that the treatment of secession becomes more like a sale of property, and cession, less. A region's citizenry would acquire tradable rights of ownership in their region, whereas a state would be able to alienate a region only if the region's citizens approved.?

3. Declaration on the Granting of Independence to Colonial Countries and Peoples, GA Res 1514 (XV), UNGAOR, 15th Sess, Supp No 2, UN Doc A/4494 (1960); Principles which should guide Members in determining whether or not an obligation exists to transmit the information called for under Article 73e of the Charter, GA Res 1541 (XV), UNGAOR, 15th Sess, UN Doc A/4526 (1960) [Principles which should guide Members].

4. See generally Antonio Cassese, Self-determination of peoples: A legal reappraisal (Cambridge, UK: Cambridge University Press, 1995). For overviews of and bibliographies on the international law on self-determination, see James Summers, "Self-Determination", Oxford Bibliographies (23 March 2012), online: <www.oxfordbibliographies.com/view/document/ obo-9780199796953/obo-9780199796953-0033.xml>; Daniel Thürer \& Thomas Burri, "Self-Determination" in Max Planck Encyclopedia of Public International Law (2008), online: Oxford Public International Law <opil.ouplaw.com/view/10.1093/law:epil/9780199231690/ law-9780199231690-e873? rskey=UIkl2f\&result=2\&prd=EPIL $>$.

5. "A Market", supra note 1.

6. Ibid at 813 .

7. Ibid at 799-800. 
International law does not conceive of other states as potential bidders, buyers, backers, underwriters or investors in a people's exercise of self-determination. Depending on their vantage point, international lawyers are likely to find the prospect of states competing in a market for territory either so far-fetched as to be unworthy of serious attention or, to the contrary, disturbingly reminiscent of the so-called "scramble for Africa" among European colonial powers in the nineteenth century. To those reflexively dismissive, the response might be that while Blocher and Gulati's proposal is unconventional, it can be debated along lines similar to earlier controversies over whether human blood or babies, for example, should be bought and sold. ${ }^{8}$ And as regards the opposite reaction-that a market in sovereignty is all too familiar-Blocher and Gulati in their longer article engage the critique that their proposal will reproduce imperialism. ${ }^{9} \mathrm{My}$ interest in the significance of the authors' analysis for international law is different. It is in commodification not as a solution, but as a set-up of the problem of self-determination: specifically, who becomes legally relevant?

In other words, the topic of this comment is a picture of self-determination, as opposed to a picture of a market. Blocher and Gulati add a third actor to the depiction of both cession and secession, but a different third actor to each. In cession between states, the citizens of the region now also figure because the authors propose to give them a say. There is, as Blocher and Gulati touch on, an international law pedigree for this shift toward popular sovereignty. ${ }^{10}$ In keeping with President Wilson's famous wartime statement- "peoples and provinces are not to be bartered about from sovereignty to sovereignty as if they were mere chattels and pawns in a game"11 —a number of disputed territories in

8. See Margaret Jane Radin, "Market-Inalienability” (1987) 100 Harv L Rev 1849;

Margaret Jane Radin, "From Baby-selling to Boilerplate: Reflections on the Limits of the Infrastructures of the Market" (2016) 54 Osgoode Hall LJ 339. See specifically Joseph Blocher, "Selling State Borders" (2014) 16 U Pa L Rev at 241 (sale of territory between US states).

9. "A Market", supra note 1 at 830-33.

10. Ibid at $812, \mathrm{n} 64$.

11. Woodrow Wilson, Address to Congress (11 February 1918) in Ray Stannard Baker and William E Dodd, eds, The Public Papers of Woodrow Wilson, War and Peace: Presidential Messages, Addresses and Public Papers 1917-1924, Volume 1 (New York and London: Harper and Brothers, 1927) at 182. 
Europe were allocated among states based on plebiscites held after World War I, ${ }^{12}$ and these were not the first such plebiscites. ${ }^{13}$

For international lawyers, the more novel inquiry is prompted by Blocher and Gulati's view of the actors relevant to secession, as distinct from cession, and to self-determination generally-or so I suggest. Here, the authors introduce other states into an exercise ordinarily analysed in terms of a people and their state. Moreover, these other states are self-interested actors. They are not representing international institutions or standing in for the international community, reflecting the status of self-determination as an erga omnes norm. ${ }^{14}$ In shifting self-determination's counterweight from the state's territorial integrity to the state's right to alienate its territory, the authors integrate the regulation of border changes sought by regions with those sought by states (not necessarily the region's own state), and they convert independence from the typical outcome into one type of purchase, namely, self-purchase. Thus, the authors' proposal not only serves peoples seeking change; it also serves, among others, states seeking to rid themselves of poor or troublesome regions and former imperial states seeking the restoration of their greater selves. ${ }^{15}$

I aim to show that, treated as an experiment in framing, Blocher and Gulati's inclusion of other states should provoke a fresh look at self-determination in international law. In particular, it should motivate international lawyers to move beyond a focus on the so-called parent state and, in cases of violence, on the alternative of responses by international institutions. Among constitutional theorists, there is already increasing caution about the romance of the idea that the people single-handedly decide their collective future. Zoran Oklopcic, for example, advocates an approach to territorial reconstruction that instead recognizes

12. See Sarah Wambaugh, Plebiscites Since the World War: With a Collection of Official Documents (Washington, DC: Carnegie Endowment for International Peace, 1933); Sarah Wambaugh, The Saar Plebiscite: With a Collection of Official Documents (Westport, Conn: Greenwood Press, 1971). But see Mai Taha, Nation and Class Subjectivity in International Law and its Institutions in the Middle East (1919-1939) (SJD Thesis, University of Toronto Faculty of Law, 2015) at 99-101 [Taha] [unpublished] (Britain successfully opposing Turkey's proposal for a plebiscite to be held in the Iraqi province of Mosul).

13. See Sarah Wambaugh, A Monograph on Plebiscites: With a Collection of Official Documents (New York: Oxford University Press, 1920).

14. Case Concerning East Timor (Portugal v Australia), [1995] ICJ Rep 90 at 102, para 29 [East Timor]; Legal Consequences of the Construction of a Wall in the Occupied Palestinian Territory, Advisory Opinion, [2004] ICJ Rep 136 at 172, para 88 [Wall Advisory Opinion].

15. "A Market", supra note 1 at 838-39. 
critically and prudentially the role of the most powerful Western states. ${ }^{16}$ And, catalyzed by the "secession" of Crimea from Ukraine to Russia, a self-determination literature is emerging in international law that foregrounds the involvement of outside actors, concerns about economic self-determination, or both. ${ }^{17}$

In turn, Blocher and Gulati's analysis might benefit from such analytical and critical stock-taking in international law. Because they draw mainly on the current secession-oriented literature, the authors are inattentive to the legal detail of decolonization as an earlier exercise of a right of self-determination. Indeed, Blocher and Gulati identify states governing "lingering colonies" as a likely type of seller in the market for sovereignty that they propose ${ }^{18}$ without noting that international law entitles these territories categorized as non-self-governing to choose their sovereign status. This entitlement is distinct from-and stronger than - the disputable and, at best, qualified entitlement of regions to secede. ${ }^{19}$ As a result, the authors neglect that the right of self-determination creates rights and duties for other states. For instance, Blocher and Gulati apply the general principle of non-intervention to conclude that existing international law prohibits other states from bidding on sovereignty, ${ }^{20}$ whereas the international legal (and embedded normative) position of other states is specific to a right of self-determination.

While this commentary relates Blocher and Gulati's proposal to the discourse of self-determination in international law, it is important to keep in mind that neither the promotion of self-determination nor compatibility with

16. Zoran Oklopcic, "Populus Interruptus: Self-Determination, the Independence of Kosovo, and the Vocabulary of Peoplehood" (2009) 22 Leiden J Intl L 677.

17. See e.g. Outi Korhonen, "Deconstructing the Conflict in Ukraine: The Relevance of International Law to Hybrid States and Wars" (2015) 16 German LJ 452 [Korhonen]; Umut Özsu, "Ukraine, International Law, and the Political Economy of Self-Determination" (2015) 16 German LJ 434. See also Edward Guntrip, "Self-Determination and Foreign Direct Investment: Reimagining Sovereignty in International Investment Law” (2016) 65 ICLQ 829 [Guntrip]; Taha, supra note 12.

18. "A Market", supra note 1 at 838.

19. Notably, Blocher and Gulati categorize East Timor's independence from Indonesia as an example of secession justified on the basis of extreme oppression. Ibid at 823, fig 1 . Contrast East Timor, supra note 14 (East Timor's right to independence as a Portuguese non-self-governing territory not altered by Indonesia's control of the territory). On the status of a qualified right to secede in international law, see Simone F van den Driest, Remedial Secession: A Right to External Self-Determination as a Remedy to Serious Injustices? (Cambridge, UK: Intersentia, 2013).

20. "Markets and Sovereignty", supra note 1 at 475; "A Market", supra note 1 at 807 . They bracket the issue of other states' recognition of new states. "A Market", supra note 1 at $817-18, \mathrm{n} 83$. 
international law is squarely their aim. Rather, their objective is to maximize "good governance" while accommodating the principles of self-determination and territorial integrity as they conceive of them. ${ }^{21}$

Accordingly, Blocher and Gulati design their market to reflect an understanding of sovereign control as legally based on good governance. It follows for them that if a state's governance of a region falls below certain standards, the state loses the ability to refuse if the region wants to leave. The state's sovereignty over the region can be involuntarily alienated, as they put it. Whether the state should receive compensation for being deprived of a misgoverned region depends on how bad its governance: no compensation in the case of genocide or oppression, and compensation (set by auction, or by the International Court of Justice (ICJ) if the price is disputed) if the region is denied representation in government or equal rights. ${ }^{22}$ These two cases, which the authors label "extreme" and "medium" oppression respectively, ${ }^{23}$ resemble certain of the categories discussed in the literature on self-determination. In particular, several international and national judgments have addressed the notion of "remedial" secession, although refrained from concluding that it has been established in international law. ${ }^{24}$

Blocher and Gulati also posit a market for sovereign control in cases where "bad governance" is not an issue. The object in these cases is to maximize welfare as determined by agreement between the group and the states involved. ${ }^{25}$ It is worth noting that the authors do not enter into whether maximizing good governance is the same as maximizing welfare. Thus, for example, in this third type of case, a change in sovereignty might be initiated by states' realpolitik interests in ceding or acquiring territory for military or other strategic reasons, ${ }^{26}$

21. "A Market", supra note 1 at 799, 805-806, 816-17.

22. Ibid at 819-22, 823, fig 1 . Compensation presumably differs in nature from the financial dimensions of state succession. See ibid at 816 (referring to compensation for "national debt, past investments, and lost natural resources"). Compare Vienna Convention on Succession of States in respect of State Property, Archives, and Debts, 8 April 1983, UN Doc A/CONF.117/14 (1983) (not yet in force).

23. Blocher \& Gulati, "A Market", supra note 1 at 819 . For clarity, I will use their terms throughout.

24. Accordance with International Law of the Unilateral Declaration of Independence in Respect of Kosovo, Advisory Opinion, [2010] ICJ Rep 403 at 438, paras 82-83 [Kosovo Advisory Opinion]; Reference re Secession of Quebec, [1998] 2 SCR 217 at paras 134-35, 161 DLR (4th) 385 [Quebec Secession Reference]; Loizidou v Turkey, ECHR 1996-VI, [1997] 23 EHRR 513 at 535 (Judge Wildhaber concurring, joined by Judge Rysdal); Katangese Peoples' Congress $v$ Zaire (1995), ACHPR Communication No. 75/92, [2000] AHRLR 72 at paras 4-6 (under African Charter on Human and Peoples' Rights).

25. Blocher \& Gulati, "A Market", supra note 1 at 819 , 823, fig 1 .

26. Ibid at 801-802. 
while the inhabitants might have very different motives for consenting to the proposed cession.

As I read them, the authors accommodate international law in their scheme for maximizing good governance and/or welfare for more than just practical reasons. They present their rules for border changes as extending the principle of self-determination so as to make international law more coherent, ${ }^{27}$ and this improved coherence also appears to feature for them as normatively desirable. ${ }^{28}$ In relating Blocher and Gulati's proposal and international law to one another, I similarly invoke international law in the sense of doctrinal walls or bridges between the two that also pose normative questions.

In Part II, I examine how coherent some of Blocher and Gulati's cases and hypotheticals are with self-determination. The most obvious unacknowledged departure is their hypothetical of the Falkland Islands/Malvinas, in which states' interests become the driving force in a colonial people's exercise of self-determination. At the same time, Blocher and Gulati's picture of the relevant legal actors in self-determination is revealing in ways that neither they nor international lawyers may immediately recognize. In Part III, I sketch three ways in which attention to the roles available to other states in self-determination complicates both Blocher and Gulati's assumptions about their proposal's proximity to existing international law, and the assumptions that many international lawyers would make about its distance. How are the sovereignty options generated in an exercise of self-determination? What rights and duties do other states have toward a people with a right of self-determination? And do the right of economic self-determination of peoples and their sovereignty over their natural resources limit the potential for other states to invest financially in a people's independence? These questions were legally salient in colonial self-determination, and Blocher and Gulati's proposal might usefully return them to our attention.

\section{UNDERMINING SELF-DETERMINATION?}

Blocher and Gulati's approach could conceivably reduce self-determination by undercutting more liberal understandings already in place in some democratic countries. In cases other than bad governance, the authors propose that the state, the region in question and (where independence is not the goal) the purchasing state must all agree on the price of the region's exit, where the price represents

27. Ibid at 805-806, 816-17; "Markets and Sovereignty", supra note 1 at 466-67, 488.

28. Blocher \& Gulati, "A Market", supra note 1 at 815. 
compensation for the loss of the region as opposed simply to the financial disentanglement involved in exit. Although the right of self-determination under international law does not give Quebec or Scotland, for example, a consent-based right to negotiate separation, their states' domestic law does. Moreover, these legal frameworks in Canada and the United Kingdom have political significance internationally and may even diffuse as a best practice to other countries via comparative constitutionalism. ${ }^{29}$ Introducing the idea of a price tag where uncommodified secession based on a referendum is already accepted may disincentivize the peaceful and timely redrawing of borders, which Blocher and Gulati list as virtues of the rule they propose for medium oppression cases involving lack of representation or equal rights. ${ }^{30}$

Deterring self-determination is not, as such, a flaw on the authors' terms since the goal of their market is to promote whatever borders would maximize good governance. This distinction is significant. In their two kinds of bad governance cases, changing borders to relieve oppression may or may not coincide with what many international lawyers would consider an exercise of self-determination. Because Blocher and Gulati do not decide on a theory of the people, ${ }^{31}$ the region entitled to exit by oppression may be home to only some fraction of a people seeking self-determination or, quite the opposite, it may not be separatist in inclination. Hence, conceiving of remedial secession as a remedy for oppression or genocide and for lack of representation or equal rights may, without more, solve less than it might appear.

Imagine an ethnic or linguistic minority group in State A that lives along a border with its kin state, State B. States A and B were once part of a single empire in which that ethnic or linguistic group was the governing class, and the group is therefore a politically well-organized minority within State A. Pursuant to a divide-and-conquer policy by State $\mathrm{A}$ in the delimitation of its subunits, the members of this group are a bare minority in each of three of the four subunits that border State B and a majority in the fourth, least prosperous subunit.

29. See Stephen Tierney, "Sovereignty and Crimea: How Referendum Democracy Complicates Constituent Power in Multinational Societies" (2015) 16 German LJ 523. Tierney argues further that international law has contributed to the moral force of referenda. Ibid at 541 .

30. "A Market", supra note 1 at 814-15.

31. Blocher and Gulati note the definition of a region as a complication. While not committing to one, they lean toward the idea that "by choosing to disfavor a particular region, a country would thereby establish both the conditions and the scope of the exit right." Ibid at 841 . See also "Markets and Sovereignty", supra note 1 at 471-72. In what follows, I illustrate the difficulties with this idea, and, in so doing, underline the need for the authors to have some theory of the people in order to make good on their claims. 
Although they are the majority of the population in the fourth subunit, a much greater number of group members is spread among the other three subunits. Let us further imagine that, unlike the other three, the fourth subunit has some lesser constitutional status or is administered in some fashion that effectively denies it representation in government. Given that Blocher and Gulati conceive of secession as a remedy of last resort for a region that lacks representation or equal rights and given that they provide no definition of the remedy-holder in other terms, then only the fourth subunit would be entitled to secede (at market price), not the minority group as a whole. While secession would solve the lack of representation or equal rights, it would not address the desire of the group as a whole to join their kin state. Indeed, the majority of the group would not be eligible to secede, even though that remainder is also territorially concentrated along the border. My point is not instrumental, but we could also imagine that the minority might be worse off because Blocher and Gulati's rules align with State A's divide-and-conquer strategy: State B might be uninterested in taking on the poorest subunit, even at its low market price, and State A might be unwilling to part with the three other subunits at any price.

To see what difference another idea of the people could make, consider two readings of remedial secession. The notion is most often traced to the articulation of self-determination in the 1970 United Nations (UN) Declaration on Friendly Relations. ${ }^{32}$ That formulation predicates protection for a state's territorial integrity and political unity on its compliance with the principle of self-determination, where that principle requires it to possess "a government representing the whole people belonging to the territory without distinction as to race, creed or colour." By negative implication, so the argument is found in the international law literature, the Declaration on Friendly Relations envisages secession as a last resort. This might mean, as just illustrated, that secession is a remedy for the misgoverned portion of the "whole people." Or it might instead remove protection for the state's territorial integrity where the "people" is a sub-state group and the exercise of their right of self-determination must ordinarily occur within the state. If this right/limit reading, as opposed to a remedy reading, is adopted, then it might follow, as some international lawyers have suggested, ${ }^{33}$ that secession is available where internal self-determination in the form of minority rights, autonomy

32. Declaration on Principles of International Law Concerning Friendly Relations and Co-operation Among States in Accordance with the Charter of the United Nations, GA Res 2625 (XXV), (1970) [Declaration on Friendly Relations].

33. See e.g. Oscar Schachter, "Sovereignty - Then and Now" in R StJ Macdonald, ed, Essays in Honour of Wang Tieya (Dordrecht, NL: Martinus Nijhoff, 1993) 671 at 684. 
or self-government is denied. Applied to our fact pattern, this interpretation would make the minority group as a whole the right holder, whereas the remedy interpretation of remedial secession would leave these options to bargaining between State A and the majority-member sub-unit.

Furthermore, if Blocher and Gulati theorize remedial secession primarily as a means to better governance, then a region may change sovereignty to achieve representative government or equal rights when it would otherwise have had no wish to become independent or join another state. The region may have no distinct identity, and its lack of representation or equality might be a legacy of racism or the aftermath of the region's economic over-exploitation as, in effect, an internal colony. ${ }^{34}$ The problem is not bad borders in the sense of some wrongful or misguided carve-up of territory in the past; it is bad government, which makes being inside the borders bad. Under these circumstances, the region could opt for remedial secession, but this remedy would come at the expense of its external self-determination in the sense of its preferred sovereign affiliation.

A similar point about trade-offs can be made about secession as a remedy for extreme oppression, the degree of bad governance that Blocher and Gulati propose should entitle a region to exit at no cost. In contrast, the closest such category of self-determination in international law assumes that the oppression is foreign-foreign military occupation ${ }^{35}$ or "alien subjugation, domination and exploitation"36 - which aligns the region's desire for a remedy with its desired sovereignty. ${ }^{37}$ Otherwise, international law emphasizes the responsibility of other states to protect populations from oppression within their existing borders.

Thus, not only do Blocher and Gulati group secession with transfers of territory initiated by the state (i.e., cession), they also leave open the possibility that secession could serve purely as a reaction to negative situations created by the state. Lastly, as the authors' hypothetical of the Falkland Islands/Malvinas shows, they are, in effect, even ready to downgrade the right of self-determination of colonial peoples to a scenario in which states are the driving force. Blocher and Gulati pose the question as follows:

In the lead-up to the Falklands War, several of Margaret Thatcher's senior advisors suggested that the United Kingdom avoid the conflict by "buying out" the few thousand residents living in the Falkland Islands and associated islands, offering

34. In some cases, the shared experience of oppression may create a distinct identity.

35. Quebec Secession Reference, supra note 24 at para 138.

36. Kosovo Advisory Opinion, supra note 24 at 438, para 82.

37. See Cassese, supra note 4 at 130 (withdrawal of occupying power assumed to be normal objective of self-determination). 
them $\$ 100,000$ per family to settle in Britain, Australia, or New Zealand. But the plan was shelved and a thousand lives were lost in the ensuing war. Now, the United Kingdom spends around $\$ 100$ million annually to maintain a military presence on the islands, Argentina continues to demand their return, and the islanders themselves have voted overwhelmingly to maintain their U.K. citizenship - which, in turn, is the primary reason for the British military presence. What if Argentina offered the islanders $\$ 1$ million each to approve a change? ${ }^{38}$

This, an international lawyer might object, is contrary to colonial self-determination. As one of a small number of remaining non-self-governing territories under the UN Charter, formerly colonies, the Falklands/Malvinas has a right of self-determination unqualified by the imperial or administering state's territorial integrity. Even though Blocher and Gulati propose to make the islanders' consent a requirement of cession to Argentina, colonial self-determination cannot simply be a matter of selling the people on an option generated by state interests. Given that they identify "lingering colonies" as likely candidates for their market in sovereignty, the authors should acknowledge and address that their proposal diminishes the role for the "self" in the existing right of self-determination of colonial peoples.

\section{REVISITING THE ROLES OF OTHER STATES IN SELF-DETERMINATION}

Might an international lawyer be too quick to fault Blocher and Gulati for de-emphasizing the desire and freedom of the "self" to determine its sovereignty and instead emphasizing its ability to supplement and choose between options put into play by states' actions? In his study of state formation after the Cold War, for example, Jure Videmar argues that the right of self-determination never makes secession an entitlement in international law, but requires that "some democratic principles be followed" in the process of state formation. ${ }^{39}$

A closer look at the right of self-determination in colonial cases suggests that even when the right was at its most undisputed, the role of the "self" might be overestimated (Section A). If so, then there is all the more reason to attend to what international law permits or requires other states to do (Section B). At the height of decolonization, when the right of self-determination was

38. "A Market", supra note 1 at 805 (footnotes omitted).

39. Jure Videmar, Democratic Statehood in International Law: The Emergence of New States in Post-Cold War Practice (Oxford: Hart Publishing, 2013) at 140-41. See also Jan Klabbers,

"The Right to be Taken Seriously: Self-Determination in International Law" (2006) 28 Hum Rts Q 186 at 189. 
taken as given, the rights and duties of other states in relation to an exercise of self-determination, as opposed to in general, were prominent issues. Insofar as Blocher and Gulati's proposal to recalibrate the principles of self-determination and territorial integrity affects the right of colonial peoples to self-determination, it would need to address the implications for these rights and duties and the justification for any departure. And, more generally, any such calibration would do well to work out anew the corresponding rights and duties of other states. The same can be said for the right of economic self-determination (Section C).

\section{A. GENERATING OPTIONS}

Although the right of UN non-self-governing territories and trust territories to self-determination is the one doctrinal certainty on which all interpretations of self-determination converge, there have nonetheless been instances of decolonization when "very small places," as Thomas Franck and Paul Hoffman once called them, ${ }^{40}$ were simply transferred to a neighbouring state with some legal claim to them. In a well-known 1975 advisory opinion of the International Court of Justice, the issue was whether the right of self-determination entitled Western Sahara, a Spanish non-self-governing territory, to a referendum on independence in the face of Morocco's and Mauritania's claims that different parts of the territory had been theirs prior to Spanish colonization. Yet the small Spanish enclave of Ifni had been handed over to Morocco in 1969 without any form of popular consultation.

The ICJ found that while Morocco and Mauritania each had some sort of legal ties to Western Sahara, these fell short of sovereignty and were not "of such a nature as might ... affect the principle of self-determination through the free and genuine expression of the will of the peoples of the Territory." ${ }^{\prime 1}$ More difficult to discern in the Court's judgment is what the effect of sovereignty or other legal ties stronger than the sorts Morocco and Mauritania established would have been. Would they have displaced the referendum, or would the referendum have had to include integration into one or both states as alternatives to independence $?^{42} \mathrm{In}$ deciding to comply with the General Assembly's request for an advisory opinion, the Court stated:

40. Thomas M Franck \& Paul Hoffman, "The Right of Self-Determination in Very Small Places" (1976) 8 NYU J Int'l L \& P 331.

41. Western Sahara, Advisory Opinion, [1975] ICJ Rep 12 at 68 [Western Sahara].

42. See Karen Knop, Diversity and Self-Determination in International Law (Cambridge, UK: Cambridge University Press, 2002) at 158-67. 
The right of self-determination leaves the General Assembly a measure of discretion with respect to the forms and procedures by which that right is to be realized ... As to the future action of the General Assembly, various possibilities exist, for instance with regard to consultations between the interested States, and the procedures and guarantees required for ensuring a free and genuine expression of the will of the people. ${ }^{43}$

Thus, even when an unqualified right of self-determination exists, how the options for sovereignty are generated remains vague. ${ }^{44}$ What if Western Sahara had wished for some transborder arrangement reflecting the nomadic patterns of its population? UN General Assembly Resolution 1541, companion to Resolution 1514 on the Granting of Independence to Colonial Countries and Peoples, states that self-determination can be realized by association with or integration into another country, as well as by independence, so long as a people freely chooses this outcome. ${ }^{45}$ The Declaration on Friendly Relations also refers to "the emergence into any other political status freely determined by a people." ${ }^{46}$ However, nothing in these resolutions guarantees that a people can choose among all of these arrangements. ${ }^{47}$

The 2014 referendum on Scottish independence gives a recent snapshot of how options are generated. It is striking how significant a role was played by future European Union (EU) membership for Scotland, and therefore the positions taken by EU states on its automaticity, in the international legal construction of the alternatives. The choice of sovereignty was not between going solo and remaining part of the United Kingdom. At the time of the referendum, it was generally understood that EU membership would not be automatic or immediate if Scotland became independent, whereas it was seemingly guaranteed by remaining in the United Kingdom. ${ }^{48}$

43. Western Sahara, supra note 41 at 36-37.

44. Antonio Cassese observes that international law does not explicitly regulate the choices available to peoples under alien military occupation and proposes four situations that should be distinguished. Cassese, supra note 4 at 147-50.

45. Principles which should guide Members, supra note 3.

46. Declaration on Friendly Relations, supra note 32.

47. Compare Oklopcic, supra note 16 (" $[\mathrm{t}]$ he contingent consensus among African nationalist elites on respecting inherited boundaries, the fact that decolonization - for the most parttook place under the umbrella of the United Nations, the existence of consensus between the United States and the Soviet Union about the desirability and contours of decolonization: all these aspects seem to have muted conceptual qualms about the external influence and the legal vocabulary of self-determination" at 681).

48. See e.g. "Nicola Sturgeon Finds an Unexpected Ally Despite Attacking his Analysis", The Guardian (11 February 2013), online: <http://www.theguardian.com/politics/ scottish-independence-blog/2013/feb/11/nicolasturgeon-scotland-treaties-legal>. 
In Blocher and Gulati's model, other states compete to buy or bankroll the people's sovereignty, but the point I seek to make here is not about a market. Rather, it is that the authors' overt attention to the role of other states in generating options for self-determination should provoke international lawyers to re-examine this subject. Commenting on efforts by some contemporary constitutional theorists to abandon or revise the idea of the constituent power of the "people" so as to recognize external involvement as inevitable, Zoran Oklopcic writes: "The constituent power of the people increasingly appears unpersuasive as great powers invade weaker ones, impose constitutional settlements, and in certain cases continue to decisively influence the operation of such constitutional orders with no clear end in sight." ${ }^{\prime 9}$ In the context of the conflict in Ukraine, Outi Korhonen goes further, drawing a complex picture of networks, private interests and business conglomerates that, she argues, should be understood legally as "hybrid statehood." 50

In turn, Blocher and Gulati might take on board the possibility of divided sovereignty. ${ }^{51}$ In response to the criticism that formal sovereignty is not necessarily as attractive a proposition as their proposal assumes, they identify a number of scenarios in which it would be. ${ }^{52}$ But their analogy between sovereignty and property could just as easily point to sovereignty as a bundle of rights to be divided up. The examples of a nomadic people and an independence movement within an EU member state suggest the relevance of shared, layered or other divided sovereignty options. The question might be, however, whether a market in sovereign rights, as opposed to full control, would sacrifice the clarity of their proposal.

49. Zoran Oklopcic, "Constitutional (Re)Vision: Sovereign Peoples, New Constituent Powers, and the Formation of Constitutional Orders in the Balkans" (2012) 19 Constellations 81 at 81 (discussing Stephen Tierney and Achilles Skordas). Other bodies of literature revisiting the idea of the constituent power extend to the involvement of international organizations (see e.g. Philip Dann \& Zaid Al-Ali, "The Internationalized Pouvoir Constituant -

Constitution-Making Under External Influence in Iraq, Sudan and East Timor" (2006) 10 Max Planck YB UN Law 423) and its value in post-national contexts such as the European Union (for a recent examination of this debate, see Nico Krisch, "Pouvoir Constituant and Pouvoir Irritant in the Postnational Order” (2016) 14 Int'l J Const'l L 657).

50. Korhonen, supra note 17.

51. Indeed, their examples in other contexts include servitudes, leases, free trade zones and special economic zones. See "A Market", supra note 1 at 801-802, 809, 836.

52. Ibid at $838-40$. 


\section{B. RIGHTS AND DUTIES OF OTHER STATES}

Because Blocher and Gulati focus on remedial secession in international lawwhich, even if legal, may not be a legal entitlement - they conclude that their proposal to give other states the right to bid for sovereign control would violate the principle of non-intervention in matters within the domestic jurisdiction of states. They do not examine the position of other states relative to a people with a clear right of self-determination, such as Western Sahara or East Timor, formerly a Portuguese non-self-governing territory. ${ }^{53}$ Relative to "lingering colonies," which have an erga omnes right of self-determination, the position of other states is regulated differently. The Declaration on Friendly Relations states:

Every State has the duty to refrain from any forcible action which deprives peoples referred to above in the elaboration of the present principle of their right to selfdetermination and freedom and independence. In their actions against, and resistance to, such forcible action in pursuit of the exercise of their right to selfdetermination, such peoples are entitled to seek and to receive support in accordance with the purposes and principles of the Charter. ${ }^{54}$

Article 20(3) of the African Charter on Human and Peoples' Rights provides: "All peoples shall have the right to the assistance of the State parties to the present Charter in their liberation struggle against foreign domination, be it political, economic or cultural." 55 Thus, if bidding on sovereignty can be construed as non-forcible assistance to a people with the right of self-determination, then Blocher and Gulati may not run afoul of international law here.

Even outside the decolonization context, in the more debatable case of remedial secession, the paragraph of the Declaration on Friendly Relations cited in support of this notion may authorize other states to take actions that they could not ordinarily take. The wording seems to imply that when a state is not in compliance, other states can take actions that would dismember or impair its territorial integrity or political unity:

Nothing in the foregoing paragraphs shall be construed as authorizing or encouraging any action which would dismember or impair, totally or in part, the territorial integrity or political unity of sovereign and independent States conducting

53. See note 19.

54. Declaration on Friendly Relations, supra note 32.

55. African Charter on Human and Peoples' Rights, 27 June 1981, 1520 UNTS 217 (entered into force 21 October 1986). 
themselves in compliance with the principle of equal rights and self-determination of peoples... ${ }^{56}$

By relating the emerging norm of the responsibility to protect $(\mathrm{R} 2 \mathrm{P})$ to the right of self-determination outside the decolonization context, Ryan Liss anticipates that other states could both assist in remedial secession and contribute to the viability of the new state. Liss proposes that $\mathrm{R} 2 \mathrm{P}$ atrocities open the door to secession if the mobilization of international efforts authorized by R2P cannot otherwise end the atrocities, and that R2P's responsibility to rebuild would apply to the new state. ${ }^{57}$

As regards the existing duties of other states, the Declaration on Friendly Relations imposes a duty on every state "to promote, through joint and separate action, realization of the principle of equal rights and self-determination of peoples, in accordance with the provisions of the Charter"- a paragraph cited by the ICJ in its advisory opinion concerning the legal consequences of the construction of a wall in the Occupied Palestinian Territory. ${ }^{58}$ Common Article 1(3) of the 1966 International Covenant on Civil and Political Rights (ICCPR) and the 1966 International Covenant on Economic, Social and Cultural Rights (ICESCR) is similar:

The States Parties to the present Covenant, including those having responsibility for the administration of Non-Self-Governing and Trust Territories, shall promote

56. Declaration on Friendly Relations, supra note 32. Although not in the secession context, Ben Saul, David Kinley and Jacqueline Mowbray, writing after the Arab Spring, speculate that even military assistance would be permitted "[w]here rebels represent a clear majority of the population and a government's repression is egregious, such an example might be a genuine case of remedial self-determination by aggrieved citizens." Ben Saul, David Kinley \& Jacqueline Mowbray, The International Covenant on Economic, Social and Cultural Rights: Commentary, Cases and Materials (Oxford: Oxford University Press, 2014) at 131 [The International Covenant].

57. Ryan Liss, "Responsibility Determined: Assessing the Relationship Between the Doctrine of the Responsibility to Protect and the Right of Self-Determination" (2011) 4 UCL Hum Rts Rev 52 at 65-67.

58. Wall Advisory Opinion, supra note 14 at 199, para 156. See also Declaration on the Right to Development, GA Res 41/128, 1986, art 5 ("States shall take resolute steps to eliminate the massive and flagrant violations of the human rights of peoples and human beings affected by situations such as those resulting from ... refusal to recognize the fundamental right of people to self-determination."). 
the realization of the right of self-determination, and shall respect that right, in conformity with the provisions of the Charter of the United Nations. ${ }^{59}$

This duty to promote is limited neither to colonial states administering non-self-governing and trust territories nor to states' duties toward their own people. ${ }^{60}$ In addition, it has been read as going beyond the negative duty to refrain from interfering in the exercise of self-determination elsewhere to encompass positive steps. In their recent commentary on the ICESCR, Ben Saul, David Kinley and Jacqueline Mowbray conclude: "Certainly states which have particular links to a foreign territory where self-determination is at issue-for instance, through trade, bonds of nationality, diplomatic influence or historical ties_-might be expected to do more." ${ }^{1}$

As applied to Blocher and Gulati's proposal, would the duty in Article 1(3) prevent charging for exit? Or, alternatively, would it require other states to contribute to the cost of exit if the people cannot muster the funds-a possibility that Blocher and Gulati speculate might sometimes be in other states' interests to avoid the rapid large-scale influx of migrants or the expense of peace-keeping operations? ${ }^{62}$

The rights and duties of other states corresponding to an established right of self-determination are no longer much scrutinized. Even when not applicable, however, they deserve attention because they provide an inventory of the aspects of other states' actions that might require reconsideration along with any proposed reformulation of self-determination.

\section{ECONOMIC SELF-DETERMINATION}

By converting independence into self-purchase in all but cases of extreme oppression (in which they conceive of the region as already "owning" its sovereignty), Blocher and Gulati create the possibility that a people seeking statehood will enter into a relationship of economic dependence with an outside state in order to finance their region's self-purchase. ${ }^{63}$ That a poorly governed region would tend to come at a lower price does not necessarily eliminate the

59. International Covenant on Civil and Political Rights, 19 December 1966, 999 UNTS 171 (entered into force 23 March 1976, accession by Canada 19 May 1976) [ICCPR]; International Covenant on Economic, Social and Cultural Rights, 19 December 1966, 993 UNTS 3 (entered into force 3 January 1976, accession by Canada 19 May 1976) [ICESCR].

60. See United Nations Human Rights Committee, General Comment No. 12: Article 1 (Right to Self-Determination), 21st Sess, UN Doc HRI/GEN/Rev.9 (Vol 1) at 183-84, para 6.

61. The International Covenant, supra note 56 at 130, 124-32 (more broadly).

62. "A Market", supra note 1 at $815,839$.

63. Ibid at 827,839 . 
need to borrow. At the limit, such a relationship could conceivably prevent a region that seceded from satisfying the criterion of independence needed to qualify for statehood. ${ }^{64}$

Third World authors have long criticized the tendency to focus on political self-determination to the neglect of economic self-determination. "But why is Spain so keen on the referendum?" asked Judge Ammoun in the Western Sahara case, pointing out that Spain stood to benefit from the combination of Western Sahara's independence plus "special privileges, as well as the grant of a right preferential to that of other countries with regard to the economic development and joint exploitation of the said territory." ${ }^{96}$ In this connection, common Article 1(2) of the ICCPR and ICESCR gives all peoples the right, for their own ends, to freely dispose of their natural wealth and resources without prejudice to any obligations arising out of international economic cooperation, with Article 25 of the ICESCR providing that nothing in that Covenant should be interpreted as "impairing the inherent right of all peoples to enjoy and utilize fully and freely their natural wealth and resources." ${ }^{37}$

Thus concerns raised by Blocher and Gulati's proposal that independence be accompanied by compensation serve to concentrate attention on two points: the financing potentially needed to achieve political self-determination (i.e., statehood), even absent a requirement for compensation; and the risk to the new state's ongoing economic self-determination posed by accepting such assistance. Judge Ammoun hints at the legalities of the continuation of economic influence by the former colonial power. What are the legalities of economic dependence on self-interested third states, and even private investors, ${ }^{68}$ created to provide the material conditions for self-determination? Conversely, a spotlight on other states

64. See e.g. James Crawford, The Creation of States in International Law, 2nd ed (Oxford: Clarendon Press, 2006) at 76-89.

65. See e.g. Mohammed Bedjaoui, Towards a New International Economic Order (Paris: UNESCO, 1979) at 87-90. On economic self-determination, in addition to the ICCPR and ICESCR, see Permanent Sovereignty Over Natural Resources, GA Res 1803 (XVII) (1962); Declaration on the Establishment of a New International Economic Order, GA Res 3201 (S-VI) (1974); Charter of Economic Rights and Duties of States, GA Res 3281 (XXIX) (1974); Declaration on the Right to Development, supra note 58; Declaration on the Rights of Indigenous Peoples, GA Res 61/295 (2007). For recent overviews, see Antony Anghie, "Legal Aspects of the New International Economic Order" (2015) 6 Humanity 145; The International Covenant, supra note 56 at 56-60, 62-67.

66. Western Sahara, supra note 41 at 100-101.

67. ICCPR, supra note 59; ICESCR, supra note 59.

68. See Blocher \& Gulati, "Markets and Sovereignty", supra note 1 at 476. Contra Guntrip, supra note 17 at 848; Korhonen, supra note 17. 
in this post-independence period might support the critique that modelling self-determination purely as an exercise of the "self" enables powerful outside states to influence state-making while having no ongoing responsibility for their part in the fate of the new state. ${ }^{69}$ Here, Liss's linkage of self-determination to the responsibility to rebuild that $\mathrm{R} 2 \mathrm{P}$ places on other states might be apposite.

In addition, a people's right to sovereignty over their natural resources invites the question: Why do Blocher and Gulati propose that a severely oppressed region be entitled merely to independence or to sell itself as is, rather than being compensated for any loss of natural resources due to bad governance? For example, Australia paid Nauru \$A107 million to settle an ICJ case brought by the small Pacific island state over the rehabilitation of certain phosphate lands mined out by Australia when it administered Nauru as a trust territory. ${ }^{70}$

\section{CONCLUSION}

By proposing to commodify the interests of outside states in a people's exercise of self-determination, Blocher and Gulati cause international lawyers to consider the roles of particular foreign states, as opposed to states in general as members of the international legal community. I have shown why Blocher and Gulati's proposal is more of a departure from international law than they acknowledge, but I have also suggested that international lawyers ought not to overestimate the differences. Held up to market-generated options for sovereignty, the generation of options pursuant to the right of self-determination appears murky in international law. Comparison with a right to bid on sovereignty raises questions about the rights and duties of other states specific to the process of self-determination. Finally, the potential to borrow from other states to finance the cost of exit restores attention to the implications of economic self-determination and a newly independent people's sovereignty over natural resources. In sum, the comparison between the idea of a market for sovereignty and the idea of self-determination as it plays out in international law raises challenges in both directions.

69. Zoran Oklopcic, Examining Choice: Self-Determination, Theories of Secession, and the Independence of Kosovo (nd) [unpublished] at 17.

70. Australia-Republic of Nauru: Settlement of the Case in the International Court of Justice Concerning Certain Phosphate Lands in Nauru (1993) 32 ILM 1471 at 1474. 